\title{
PENGARUH MODEL PEMBELAJARAN TERHADAP HASIL BELAJAR MATEMATIKA DITINJAU DARI KEMANDIRIAN BELAJAR SISWA
}

\section{THE EFFECT OF LEARNING MODELS ON MATHEMATICS LEARNING RESULTS VIEWED FROM STUDENTS 'INDEPENDENCE}

\author{
AI SOLIHAH \\ Program Studi Informatika, Universitas Indraprasta PGRI \\ TB. Simatupang, Jl. Nangka Raya No.58 C, RT.5/RW.5, Tj. Bar., Kec. \\ Jagakarsa, Kota Jakarta Selatan, Daerah Khusus Ibukota Jakarta 12530 \\ Ponsel : 085223957935 \\ Surel: faztasy@yahoo.com
}

\begin{abstract}
Abstrak
Tujuan dari penelitian ini adalah untuk menganalisis pengaruh penggunaan hasil belajar matematika siswa pada SMK Swasta di Kabupaten Bogor. Metode yang digunakan adalah metode eksperimen. Dalam penelitian ini eksperimen dilakukan dengan membandingkan dua buah model pembelajaran yaitu model pembelajaran TPS (Think Pair Share) dan model pembelajaran konvensional. Dalam penelitian ini, mempunyai tiga variabel yaitu model pembelajaran, Kemandirian Belajar dan hasil belajar matematika. Sebelum melakukan uji hipotesis, terlebih dahulu dilakukan uji persyaratan data diantaranya: pengujian normalitas dan reliabilitas. Hasil pengujian hipotesis pada hasil penelitian ini menunjukkan bahwa: (1) Terdapat pengaruh yang signifikan model pembelajaran terhadap hasil belajar matematika (2) Terdapat pengaruh yang signifikan kemandirian belajar terhadap hasil belajar matematika (3) Terdapat pengaruh interaktif yang signifikan model pembelajaran dan kemandirian belajar terhadap hasil belajar matematika.
\end{abstract}

Kata Kunci : Model Pembelajaran, Kemandirian Belajar, Hasil Belajar Matematika.

\begin{abstract}
The purpose of this study was to analyze the effect of the use of student mathematics learning outcomes at Private Vocational Schools in Bogor Regency. The method used is an experimental method. In this study the experiment was conducted by comparing two learning models namely the TPS (Think Pair Share) learning model and the conventional learning model. In this study, it has three variables, namely the learning model, Learning Independence and mathematics learning outcomes. Before conducting a hypothesis test, firstly testing the data requirements including: normality and reliability testing. Hypothesis testing results on the results of this study indicate that: (1) There is a significant effect of learning models on mathematics learning outcomes (2) There is a significant influence of learning independence on mathematics learning outcomes (3) There is a significant interactive effect of learning models and learning independence on mathematics learning outcomes.
\end{abstract}

Keywords: Learning Model, Learning Independence, Mathematics Learning Outcomes. 
PENDAHULUAN

Matematika adalah salah satu bidang ilmu yang dijadikan sebagai mata pelajaran pokok di sekolah dari tingkat kanak-kanak sampai perguruan tinggi. Oleh karena itu, pelajaran matematika memegang peranan yang sangat penting dalam mengembangkan pola pikir bagi siswa. Hal ini sejalan dengan salah satu tujuan umum diberikanya matematika pada jenjang pendidikan dasar yaitu mempersiapkan siswa agar dapat menggunakan matematika dan pola pikir matematika dalam kehidupan sehari-hari dan dalam mempelajari berbagai ilmu pengetahuan.

Rendahnya hasil belajar matematika tentu dipengaruhi oleh beberapa faktor antara lain: faktor internal dan faktor eksternal. Faktor internal meliputi: kecerdasan/ intelegensi, bakat, minat, dan motivasi. Sedangkan faktor eksternal meliputi: pengalaman, keadaan keluarga, keadaan sekolah dan lingkungan sekitar. Kedua faktor tersebut sangat berpengaruh penting dan saling mendukung dalam peningkatan belajar siswa.

Dalam proses belajar mengajar anak didik merupakan subjek dan guru sebagai objek yang berperan secara aktif, dinamis dan interaktif. Salah satu komponen yang paling penting mendapatkan perhatian khusus adalah anak didik sebagai subjek yang berperan dalam kemajuan pendidikan. Peranan keluarga dan masyarakat sangatlah penting, untuk terbentuknya kemandirian pada diri siswa dan terbiasa untuk melakukan suatu kegiatan baik dilakukan sendiri maupun gotong royong dengan masyarakat.

Berdasarkan latar belakang, maka penulis merumuskan masalah penelitiannya yaitu: Apakah terdapat pengaruh model pembelajaran terhadap hasil belajar matematika?. Apakah terdapat pengaruh kemandirian belajar terhadap hasil belajar matematika?. Apakah terdapat pengaruh interaktif model pembelajaran dan kemandirian belajar terhadap hasil belajar matematika?

Berdasarkan rumusan masalah diatas, maka penelitian ini bertujuan untuk mengetahui: Pengaruh model pembelajaran terhadap hasil belajar matematika. Pengaruh kemandirian belajar terhadap hasil 
belajar matematika. Pengaruh interaktif model pembelajaran dan kemandirian belajar terhadap hasil belajar matematika.

Dari landasan teori dan kerangka berpikir di atas penulis dapat menentukan hipotesis penelitian sebagai berikut: Terdapat pengaruh yang signifikan model pembelajaran terhadap hasil belajar matematikaTerdapat pengaruh yang signifikan kemandirian belajar terhadap hasil belajar matematika. Terdapat pengaruh interaktif yang signifikan model pembelajaran dan kemandirian belajar terhadap hasil belajar matematika

\section{KAJIAN TEORITIK}

Model pembelajaran adalah suatu perencanaan atau suatu pola yang digunakan sebagai pedoman dalam merencanakan pembelajaran di kelas atau pembelajaran dalam tutorial dan untuk menentukan perangkatperangkat pembelajaran. Dengan demikian model pembelajaran mengarahkan guru dalam membuat desain pembelajaran untuk membantu siswa mencapai tujuan pembelajaran (Trianto, 2009).
Model pembelajaran adalah kerangka konseptual yang melukiskan prosedur secara sistematis dalam mengorganisasikan pengalaman belajar untuk mencapai tujuan belajar tertentu, dan berfungsi sebagai pedoman dalam merencanakan kegiatan pembelajaran (Trianto, 2009). Pengertian ini memberikan gambaran bahwa model pembelajaran bagaimana seorang guru merencanakan proses pembelajaran yang sistematis dengan pengalaman belajar yang diorganisir sehingga proses belajar berjalan efektif agar siswa dapat mencapai tujuan pembelajaran tertentu.

Pembelajaran kooperatif adalah model pembelajaran yang digunakan dalam mewujudkan kegiatan belajar mengajar yang berpusat pada siswa (student oriented), terutama dalam mengatasi permasalahan yang ditemukan guru dalam mengaktifkan siswa, yang tidak dapat bekerja sama dengan orang lain, siswa yang agresif dan tidak peduli pada yang lain. Model pembelajaran ini telah terbukti dapat dipergunakan dalam 
berbagai mata pelajaran dan berbagai usia (Isjoni, 2013)

TPS (Think Pair Share) atau (Berpikir Berpasangan Berbagi) merupakan jenis pembelajaran kooperatif yang dirancang untuk mempengaruhi pola interaksi siswa. TPS menghendaki siswa bekerja saling membantu dalam kelompok kecil (2-6 anggota) dan lebih dirincikan oleh penghargaan kooperatif, daripada penghargaan individual (Arzak \& Ibrahim, 2017)

Pembelajaran Think Pair Share pertama kali dikembangkan oleh Profesor Frank Lyman di Universitas Maryland pada tahun 1981. Pembelajaran TPS ini merupakan tipe yang sederhana dengan banyak keuntungan karena dapat mengoptimalisasikan partisipasi siswa untuk mengeluarkan pendapatnya dan meningkatkan pembentukan pengetahuan oleh siswa. Selain itu tipe ini memberikan kesempatan kepada siswa untuk berpikir, yaitu bekerja sendiri sebelum bekerja sama dengan kelompoknya, dan berbagi ide, yaitu setiap siswa saling memberikan ide atau informasi yang mereka ketahui tentang soal yang diberikan untuk memperoleh kesepakatan dari penyelesaian soal tersebut. Para siswa dan guru akan memperoleh pemahaman yang lebih besar akibat perhatian dan partisipasinya dalan diskusi kelas.

Istilah belajar sebenarnya telah lama dan banyak dikenal. Bahkan pada jaman sekarang ini, hampir semua orang mengenal istilah belajar. Belajar merupakan proses yang berlangsung seumur hidup, baik yang dilaksanakan pada lembaga pendidikan formal maupun non-formal. Belajar juga merupakan aktivitas manusia yang penting dan tidak dapat dipisahkan dari kehidupan manusia, mulai dari manusia dilahirkan sampai akhir hayatnya.

Mengatakan bahwa: "Belajar adalah suatu perubahan tingkah laku yang berupa pengetahuan (kognitif), sikap (afektif) dan keterampilan (psikomotorik) yang dialami siswa melalui tahap-tahap tertentu mengenai suatu persoalan dari suatu latihan atau pengalaman yang dapat dipengaruhi oleh faktor internal dan eksternal" (Suhendri, 2015).

Hasil belajar adalah kegiatan yang berhubungan dengan perubahan tingkah laku manusia, yang diakibatkan oleh pengalaman. 
Hal tersebut diperoleh dari pengetahuan, perilaku, dan keterampilan, melalui jalan latihan yang senantiasa di landasi oleh itikad dan tujuan tertentu (Haryanto, 2015) .

Hasil adalah prestasi dari suatu kegiatan yang telah dikerjakan, diciptakan, baik secara individu maupun kelompok. Hasil tidak akan pernah dihasilkan selama orang tidak melakukan sesuatu". Untuk menghasilkan sebuah prestasi dibutuhkan perjuangan dan pengorbanan yang sangat besar. Hanya dengan keuletan, sungguh-sungguh, kemauan yang tinggi dan rasa optimisme dirilah yang mampu untuk mancapainya (Djamarah \& Zain, 2010).

Sedangkan belajar adalah bukan suatu tujuan tetapi merupakan proses untuk mencapai tujuan. Belajar adalah modifikasi atau memperteguh kelakuan melalui pengalaman (Hamalik, 2010). Jadi belajar diartikan sebagai proses perubahan tingkah laku pada diri individu berkat adanya interaksi antara individu dan individu dengan lingkungan.

Hasil belajar ialah hasil yang dicapai dalam bentuk angka-angka atau skor setelah diberikan tes hasil belajar pada setiap akhir pembelajaran. Nilai yang diperoleh siswa menjadi acuan untuk melihat penguasaan siswa dalam menerima materi pelajaran (Dimyati dan Mudjiono, 2006). Hasil belajar adalah kemampuankemampuan yang dimiliki siswa setelah ia menerima pengalaman belajarnya (Sudjana, 2009).

Setelah mengetahui uraian di atas tentang pengertian hasil dan belajar, dapat dipahami bahwa hasil pada dasarnya adalah prestasi yang diperoleh dari sesuatu aktivitas. Sedangkan belajar adalah suatu proses yang mengakibatkan perubahan dalam diri individu, yakni perubahan tingkah laku.

Dengan demikian dapat ditarik kesimpulan bahwa hasil belajar adalah kemampuan yang diperoleh siswa sebagai hasil dari apa yang dipelajarinya di sekolah, yang relatif menetap dalam potensi tingkah laku yang terjadi sebagai akibat dari latihan dengan pengetahuan. Siswa yang belajar akan memperoleh hasil dari apa yang telah dipelajarinya selama proses belajar tersebut. 


\begin{abstract}
Matematika adalah suatu ilmu yang mempelajari bilangan, bangun, dan konsep-konsep yang berkenaan kebenarannya secara logika, menggunakan simbolsimbol yang umum serta aplikasi dalam bidang lainnya (Fahrudin Amirulloh, 2013) .

Dalam belajar matematika diperlukan pemahaman dan penguasaan materi terutama dalam membaca simbol, tabel dan diagram yang sering digunakan dalam matematika serta struktur matematika yang kompleks, dari yang konkret sampai yang abstrak, apalagi jika yang diberikan adalah soal dalam bentuk cerita yang memerlukan kemampuan penerjemahan soal ke dalam kalimat matematika dengan memperhatikan maksud dari pertanyaan soal tersebut.
\end{abstract}

\section{METODE PENELITIAN}

Penelitian ini menggunakan metode quasi eksperimen, yaitu dengan memberikan jenis perlakuan yang berbeda pada dua kelompok belajar siswa. Satu kelompok dijadikan sebagai kelompok eksperimen, yaitu diberikan perlakuan pembelajaran Matematika dengan model Think Pair Share (TPS), sedangkan kelompok yang satu lagi merupakan kelompok kontrol yang diberikan perlakuan model pembelajaran Konvensional.

Dari masing-masing kelompok kemudian dibagi kedalam siswa memiliki kemandirian belajar tinggi dan siswa memiliki kemandirian belajar rendah. Penelitian ini menggunakan desain treatment by level. Pengumpulan data tentang kemandirian belajar siswa dilakukan dengan penyebaran angket pada siswa kelas $X \quad$ Administrasi Perkantoran SMK Al- Basyariah dan SMK Mandiri di kabupaten Bogor sebagai sampel penelitian.

\section{HASIL PENELITIAN DAN PEMBAHASAN}

Berdasarkan hasil pengujian pada Test of Between-Subject Effects di atas yang merupakan tabel utama (main effect) yang mempresentasikan hasil hipotesis yang diajukan peneliti. Dari tabel tersebut, untuk kategori Teams Games Tournament dan Student Teams-Achievement Divisions (A) memiliki nilai sig 0,001 < 0,05 dan $F_{\text {hitung }}=13,55$ maka $H_{0}$ ditolak dan $\mathrm{H}_{1}$ diterima. Sehingga dapat disimpulkan bahwa terdapat pengaruh yang signifikan model pembelajaran terhadap hasil belajar Matematika. 
Berdasarkan Hasil pengujian pada tabel Test of Between-Subject Effects diketahui untuk kategori kemandirian belajar tinggi dan rendah (B) memiliki nilai sig 0,005 0,05 dan $\mathrm{F}_{\text {hitung }}=8,479$ maka maka $\mathrm{H}_{0}$ ditolak dan $\mathrm{H}_{1}$ diterima. Sehingga dapat disimpulkan terdapat pengaruh yang signifikan kemandirian belajar terhadap hasil belajar Matematika.

Berdasarkan hasil pengujian yang terdapat pada tabel Test of Between-Subject Effects diperoleh nilai $p$-value untuk interaktif model pembelajaran dan kemandirian belajar $\left(A^{*} B\right)$ memiliki nilai sig 0,047 < 0,050 dan $F_{\text {hitung }}=4,132$ maka maka $\mathrm{H}_{0}$ ditolak dan $\mathrm{H}_{1}$ diterima. Sehingga dapat disimpulkan terdapat pengaruh interaktif yang signifikan antara model pembelajaran dan kemandirian belajar terhadap hasil belajar Matematika.

\section{SIMPULAN}

Adapun simpulan yang dapat diambil dari penelitian ini adalah: Terdapat pengaruh yang signifikan model pembelajaran terhadap hasil belajar Matematika. Hal ini dibuktikan dengan sig 0,001<0,05 dan $F_{\text {hitung }}$ 13,55. Terdapat pengaruh yang signifikan kemandirian belajar siswa terhadap hasil belajar Matematika.
Hal ini dibuktikan dengan nilai sig $0,005<0,05$ dan $F_{\text {hitung 8,479. }}$ Terdapat pengaruh interaktif yang signifikan model pembelajaran dengan kemandirian belajar siswa terhadap hasil belajar Matematika. Hal ini dibuktikan oleh nilai sig 0,047<0,05 dan F-hitung 4,132.

\section{DAFTAR PUSTAKA}

Andri Fahrudin Amirulloh.

"Kemampuan Number Sense

Siswa Kelas VII SMP dalam

Menyelesaikan Masalah

Matematika Ditinjau dari

Perbedaan Jenis Kelamin.”

Skripsi, UNESA, 2013.

Arzak, \& Ibrahim, M. "Efektivitas

Model Pembelajaran Kooperatif Tipe Two Stay Two Stray (TSTS) Terhadap Hasil Belajar Matematika Siswa Kelas Viii Smp Negeri 10 Kendari Pada Pokok Bahasan Operasi Bentuk Aljabar". Jurnal Penelitian Pendidikan Matematika Volume 3, No. 1, 2017.

Dimyati dan Mudjiono. Belajar dan Pembelajaran. Jakarta: Rineka Cipta, 2006.

Djamarah, S. B., \& Zain, A. Guru dan Anak Didik dalam Interaksi Edukatif Suatu Pendekatan Teoritis Psikologis. Jakarta: Rineka Cipta, 2010. 
Hamalik, Oemar. Proses Belajar Mengajar. Jakarta: PT Bumi Aksara, 2010.

Isjoni. "Cooperatif learning." In Book.https://doi.org/10.1177/002

0715216667452 ( Diakses 15 Januari 2019).

Slavin, R. E. Cooperative learning. Bandung: Nusa Media, 2013.

Sudjana, Nana. Penilaian Hasil Proses Belajar Mengajar. Bandung: PT. Remaja

Rosdakarya, 2016.

Suhendri, H. "Pengaruh Metode

Pembelajaran Problem Solving terhadap Hasil Belajar

Matematika Ditinjau dari Kemandirian Belajar". Formatif: Jurnal IImiah Pendidikan MIPA. https://doi.org/10.30998/formatif. v3i2.117 (Diakses 15 Januari 2019)

Suyono \& Hariyanto, Implementasi Belajar \& Pembelajaran. Bandung: Remaja Rosdakarya, 2015.

Trianto. Mendesain model pembelajaran inovatif progresif. Surabaya: Kencana, 2009. 